\title{
Clinical and molecular aspects of severe malaria
}

\author{
KARIN KIRCHGATTER ${ }^{1}$ and HERNANDO A. DEL PORTILLO ${ }^{2}$ \\ ${ }^{1}$ Núcleo de Estudos em Malária, Superintendência de Controle de Endemias (SUCEN)/ \\ Instituto de Medicina Tropical de São Paulo (IMTSP), Universidade de São Paulo (USP) \\ 05403-000 São Paulo, SP, Brasil \\ ${ }^{2}$ Departamento de Parasitologia, Instituto de Ciências Biomédicas, Universidade de São Paulo (USP) \\ 05508-900 São Paulo, SP, Brasil
}

Manuscript received on March 3, 2005; accepted for publication on March 28, 2005; presented by George A. DosReIs

\begin{abstract}
The erythrocytic cycle of Plasmodium falciparum presents a particularity in relation to other Plasmodium species that infect man. Mature trophozoites and schizonts are sequestered from the peripheral circulation due to adhesion of infected erythrocytes to host endothelial cells. Modifications in the surface of infected erythrocytes, termed knobs, seem to facilitate adhesion to endothelium and other erythrocytes. Adhesion provides better maturation in the microaerophilic venous atmosphere and allows the parasite to escape clearance by the spleen which recognizes the erythrocytes loss of deformability. Adhesion to the endothelium, or cytoadherence, has an important role in the pathogenicity of the disease, causing occlusion of small vessels and contributing to failure of many organs. Cytoadherence can also describe adhesion of infected erythrocytes to uninfected erythrocytes, a phenomenon widely known as rosetting. Clinical aspects of severe malaria, as well as the host receptors and parasite ligands involved in cytoadherence and rosetting, are reviewed here. The erythrocyte membrane protein 1 of P. falciparum (PfEMP1) appears to be the principal adhesive ligand of infected erythrocytes and will be discussed in more detail. Understanding the role of host receptors and parasite ligands in the development of different clinical syndromes is urgently needed to identify vaccination targets in order to decrease the mortality rates of this disease.
\end{abstract}

Key words: severe malaria, Plasmodium falciparum, PfEMP1, pathogenesis, cytoadherence, rosetting, antigenic variation.

\section{INTRODUCTION}

Malaria is the most important tropical disease and causes death of more people than any other transmissible disease, except tuberculosis. Approximately $36 \%$ of the world population lives in risk areas. Worldwide estimates of patient numbers is around 515 million annually, and 1.5 to 2.7 million people die due to complications, including 1 million chil-

Correspondence to: Karin Kirchgatter

E-mail: karink@usp.br dren of less than five years of age (one child every 40 seconds). Other groups at high risk are women during their first pregnancies and non-immune travellers. Plasmodium falciparum is responsible for most of the infections and almost all deaths, occurring in many countries but mainly in the African continent (rev. in Breman 2001 and Snow et al. 2005).

The World Health Organization (WHO) listed 101 countries or territories as endemic for malaria: 45 African, 21 American, 4 European, 14 in the east 
Mediterranean, 8 in southeast Asia and 9 in the west Pacific area. However, more than $70 \%$ of all malaria cases are in Sub-Saharan Africa. Of the non-African cases, two-thirds of malaria infected people are concentrated in only 6 countries. In increasing order of incidence these countries are: the Salomon Islands, Colombia, Vietnam, Sri Lanka, Brazil and India (WHO 1996).

In Brazil, $99.7 \%$ of malaria cases are concentrated in the Amazon Region, mainly in Amazonas, Pará, and Rondônia States, which together are responsible for $85 \%$ of the cases (Figure 1). In three consecutive years (1996, 1997 and 1998), the number of cases registered in Brazil was inferior to 500,000 . However, in 1999, the official number increased 34\% $(637,000)$, including an increment of $15 \%$ in the $P$. falciparum infections. In 2000 , there was stabilization $(615,000)$ and in 2001 there was a decrease $(389,000)$ in the number of cases notified. In $2002(349,000)$ and again in $2003(405,000)$ this number remained stable. P. falciparum was responsible for $21.5 \%$ of the infections in 2003. The registration of malaria mortality varies in the Brazilian States and is limited, irregular and imprecise, but around 150 deaths due to malaria are registered annually in Brazil (http://dtr2001.saude.gov.br/svs/ epi/situacao_doencas/transmissiveis00.htm).

\section{CLINICAL ASPECTS OF SEVERE MALARIA}

Severe malaria defines infection with manifestations and complications that are potentially fatal in man causing 15 to $20 \%$ mortality in spite of effective drugs and correct medical aid. Annually, 5 to 10 million infected individuals develop complications during infection, manifested as coma (cerebral malaria), metabolic acidosis, hypoglycemia, severe anemia, renal failure and lung edema, with frequency varying according to the level of malaria transmission in the area (rev. Miller et al. 1994, 2002) (Table I).

In many parts of the world, cerebral dysfunction is the more common severe manifestation of falciparum malaria and the main cause of death in adults with severe disease. The obstruction of cere- bral venules and capillaries with erythrocytes containing mature trophozoites and schizonts causes generalized convulsion and coma and a mortality rate from 4 to $50 \%$. In Thailand and Vietnam, half of the severe falciparum cases are cerebral malaria (Tran et al. 1996), while in other places, like Papua New Guinea, this number decreases to $17 \%$ (Lalloo et al. 1996). In Brazil, the number of cerebral malaria cases is not available but the few studies published on severe falciparum malaria in Brazilian patients point to renal failure and respiratory distress as the main complications (Duarte et al. 1985, Corbett et al. 1989, Boulos 1992).

Acute pulmonary edema is also a common fatal complication, presenting interstitial edema with swollen endothelial cells and monocytes narrowing the capillary lumen. The edematous interstitium also contains macrophage with endocytes and malarial pigment (Duarte et al. 1985).

Acute renal failure is another important complication in severe malaria and is defined as an increase in the serum creatinine to above $3 \mathrm{mg} / \mathrm{dL}$ or an increase in blood urea above $40 \mathrm{mg} \%$. Patients with acute renal failure without involvement of multiple organs have a good prognosis if peritoneal dialysis is accomplished. In Vietnam, half of the patients with severe malaria presented biochemical evidence of renal involvement (serum creatinine $>2 \mathrm{mg} / \mathrm{dL}$ ), however only $30 \%$ filled the WHO criteria for acute renal failure and half of them needed dialysis. Half of the patients with renal failure present lung edema and $45 \%$ of these die (WHO 2000).

Laboratory data are important for the diagnosis of severe malaria. Anemia $(\mathrm{Hb}<7 \mathrm{~g} / \mathrm{dL}, \mathrm{Ht}<20 \%)$ is an inevitable consequence of severe malaria and jaundice (total serum bilirubin $>3 \mathrm{mg} / \mathrm{dL}$ ) is common in patients with acute renal failure and parasitemia above $100,000 / \mathrm{mm}^{3}$ (WHO 2000). Another important aspect of severe malaria is the degree of neutrophiles (but not monocytes) containing malarial pigment that, in hypoendemic areas, has been used to predict the gravity of infection, with sensibility and specificity greater than $73 \%$ (Nguyen et al. 1995). In hyperendemic areas, there is no corre- 


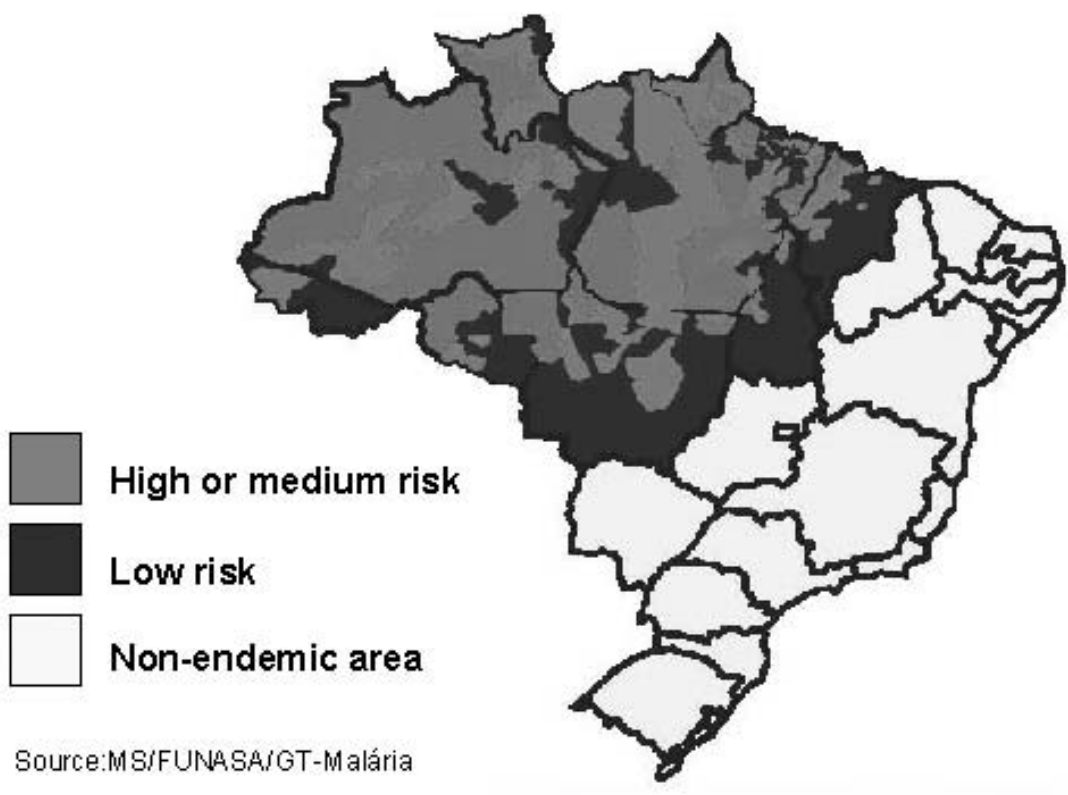

Fig. 1 - Malaria risk areas in Brazil.

TABLE I

Main manifestations of severe malaria as related to age-group in areas of different malaria endemicity.

\begin{tabular}{l|l|l}
\hline Transmission & Main manifestations of severe malaria & Age-group \\
\hline High & Anaemia & Young children \\
\hline \multirow{2}{*}{ Intermediate } & Cerebral malaria and metabolic acidosis & Children \\
\hline \multirow{2}{*}{ Low } & Renal failure and pulmonary oedema & Adults \\
\cline { 2 - 3 } & Anaemia and hypoglycaemia & Children \\
\cline { 2 - 3 } & Cerebral malaria and metabolic acidosis & Adults and children \\
\hline
\end{tabular}

Adapted from WHO 1990, Luxemburger et al. 1996, Snow et al. 1997.

lation between neutrophiles or even monocytes with pigment and severe malaria (Metzger et al. 1995). Other laboratory data used to predict malaria severity is the serum procalcitonin level. Procalcitonin (PCT) is a known sepsis marker and is undetectable in healthy individuals (Assicot et al. 1993). The origin and function of PCT are not well understood, but PCT production probably occurs in the cells of the monocyte-macrophage system (Oberhoffer et al. 1999), mediating a secondary response that increases the inflammatory response (Whang et al. 1999). In severe malaria patients, PCT concentrations before treatment were found to be directly pro- portional to the parasitemia. The lowest PCT concentrations were found in semi-immune patients and the highest PCT concentrations were obtained in severe malaria patients, from which $85.7 \%$ with PCT levels $>25 \mathrm{ng} / \mathrm{ml}$ died (Hollenstein et al. 1998, Chiwakata et al. 2001).

It is important to note that malaria is a systemic disease where different systems are affected due to infection of the erythrocytes (Boulos 1992, rev. in Miller et al. 2002). The signs and symptoms of severe malaria indicate a complex syndrome, established by host and parasite factors. The main virulence phenotypes are related to cytoadherence, 


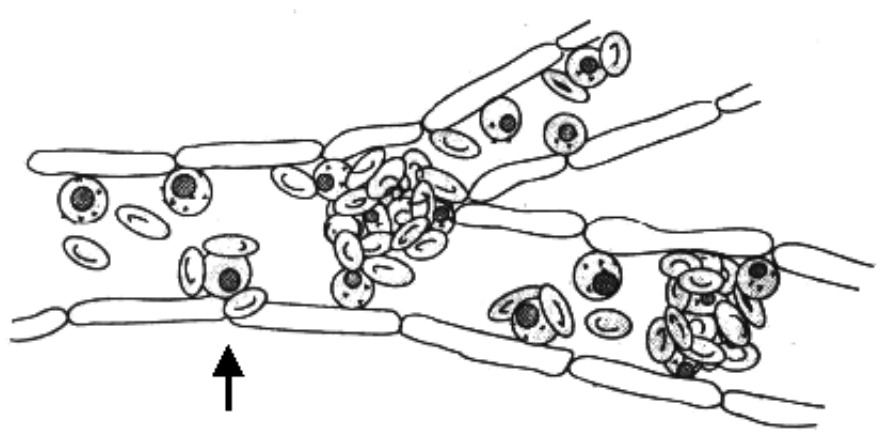

Fig. 2-Schematic representation of rosetting and cytoadherence leading to vessels obstruction. Parasites inside red blood cells are depicted as black circles. Arrow shows an infected red blood cell involved in both cytoadherence and rosetting (Adapted from Wahlgren et al. 1992).

rosetting and antigenic variation.

\section{MOLECULAR ASPECTS OF SEVERE MALARIA}

\section{Sequestration and Cytoadherence}

The erythrocytic cycle of $P$. falciparum presents a particularity in relation to other Plasmodium species that infect man. Mature trophozoites and schizonts are sequestered in the peripheral circulation (Bignami and Bastianelli 1889), due to adhesion of infected erythrocytes to endothelial cells (Miller 1969). Modifications on the surface of the infected erythrocytes, denominated knobs, provide adhesion sites for endothelium and other erythrocytes (Luse and Miller 1971). It is amply accepted that adhesion to other surfaces leads to better maturation in the microaerophilic venous atmosphere and allows the parasite to escape clearance by the spleen. Sequestration was also observed in primate and rodent malaria. Adhesion to the endothelium, or cytoadherence, has an important role in the pathogenicity of the disease causing occlusion of small vessels and contributing to the failure of many organs (Figure 2) (Miller et al. 1994).

\section{Host RecePtors ImPlicAted IN CytoAdHERENCE}

Several molecules have already been identified as endothelial receptors based on their ability to support the adhesion of infected erythrocytes during in vitro assays (Table II).
Thrombospondin (TSP) was the first molecule described as a cytoadherence receptor (Roberts et al. 1985) and demonstrated to bind to an erythrocyte membrane protein, termed PfEMP1 (Baruch et al. 1996). However, the PfEMP1 domain responsible for the adhesion to TSP has not been precisely mapped. As PfEMP1 is implicated in several aspects of severe malaria and pathogenesis, it will be described and discussed separately below.

CD36, the second molecule to be implicated in cytoadherence (Barnwell et al. 1989), is found on monocytes, endothelial cells, platelets and erythroblasts. In spite of high sequence polymorphism, PfEMP1 binds to $\mathrm{CD} 36$ via the $\mathrm{CIDR} \alpha$ domain (Baruch et al. 1997), and all CIDR $1 \alpha$ domains of the 3D7 clone bind to CD36 (Robinson et al. 2003). Indeed, it was demonstrated that a recombinant CIDR sub fragment of 179 residues pertaining to the CD36 binding area, inhibits and reverts adhesion of the infected erythrocytes to the receptor in four different lines of parasites (Cooke et al. 1998).

Intercellular adhesion molecule 1 (ICAM-1) is an endothelial molecule that also acts as receptor for infected erythrocytes (Berendt et al. 1989). The binding site on ICAM-1 has been mapped to the junction of the first and second immunoglobulinlike domains (Berendt et al. 1992). The DBL2 $\beta$ domain of PfEMP1, together with the $\mathrm{C} 2$ domain, binds to ICAM-1 (Smith et al. 2000a). ICAM-1 has been shown to have an important role in cerebral 
TABLE II

Host receptors and parasite ligands involved in cytoadherence. Host receptors: TSP (thrombospondin), CD36 (cluster of differentiation 36), ICAM-1 (intercellular adhesion molecule 1), ELAM-1 (endothelial leukocyte adhesion molecule 1), VCAM-1 (vascular cell adhesion molecule 1), CSA (chondroitin4-sulfate), HA (hyaluronic acid), HS (heparan sulfate), PECAM-1 (platelet-endothelial cell adhesion molecule 1). Parasite ligands: PfEMP1 (P. falciparum erythrocyte membrane protein 1). Domains: DBL (Duffy binding-like), CIDR (cysteine rich interdomain region). CLAG (cytoadherence-linked asexual gene). STEVOR (subtelomeric variant open reading frame).

\begin{tabular}{|c|c|c|c|}
\hline $\begin{array}{l}\text { Host receptors } \\
\text { (synonymous) }\end{array}$ & $\begin{array}{l}\text { Parasite ligands } \\
\text { (domain) }\end{array}$ & $\begin{array}{l}\text { Relevant remarks } \\
\text { of each interaction }\end{array}$ & References \\
\hline TSP & PfEMP1 & $\begin{array}{l}\text { Low affinity of binding } \\
\text { in flow conditions }\end{array}$ & $\begin{array}{l}\text { (Roberts et al. 1985, } \\
\text { Baruch et al. 1996) }\end{array}$ \\
\hline CD36 & PfEMP1 (CIDR1 $\alpha)$ & Most common binding phenotype & $\begin{array}{l}\text { (Oquendo et al. 1989, } \\
\text { Barnwell et al. 1989, Baruch } \\
\text { et al. 1995, 1996, 1997) }\end{array}$ \\
\hline ICAM-1 (CD54) & PfEMP1 (DBL2 $\beta$ C2) & $\begin{array}{l}\text { Receptor member of the } \\
\text { immunoglobulin superfamily }\end{array}$ & $\begin{array}{l}\text { (Berendt et al. 1989, 1992, } \\
\text { Baruch et al. 1996, Smith } \\
\text { et al. 2000a) }\end{array}$ \\
\hline $\begin{array}{l}\text { ELAM-1 (CD62E) } \\
\text { (E-selectin) }\end{array}$ & $?$ & Uncommon target of binding & (Ockenhouse et al. 1992) \\
\hline VCAM-1 (CD106) & $?$ & $\begin{array}{l}\text { Receptor member of the } \\
\text { immunoglobulin superfamily/ } \\
\text { Uncommon target of binding }\end{array}$ & $\begin{array}{l}\text { (Ockenhouse et al. 1992, } \\
\text { Newbold et al. 1997a, b) }\end{array}$ \\
\hline P-selectin & PfEMP1 & $\begin{array}{l}\text { Binding is } \mathrm{Ca}^{2+} \text {-dependent; } \\
\text { ligand is questioned }\end{array}$ & (Ho et al. 1998) \\
\hline CSA & $\begin{array}{l}\text { PfEMP1 (DBL3 } \gamma) \\
(\mathrm{CIDR} 1)\end{array}$ & $\begin{array}{l}\text { Binding important in malaria } \\
\text { during pregnancy }\end{array}$ & $\begin{array}{l}\text { (Rogerson et al. 1995, } \\
\text { Fried and Duffy 1996, } \\
\text { Buffet et al. 1999, } \\
\text { Reeder et al. 1999) }\end{array}$ \\
\hline HA & PfEMP1 & $\begin{array}{l}\text { Receptor that mediates } \\
\text { adhesion to placenta }\end{array}$ & (Beeson et al. 2000) \\
\hline HS & PfEMP1 (DBL1 $\alpha)$ & $\begin{array}{l}\text { Receptor presents in endothelial } \\
\text { cells and aorta }\end{array}$ & $\begin{array}{l}\text { (Barragan et al. 2000b, } \\
\text { Vogt et al. 2003) }\end{array}$ \\
\hline PECAM-1 (CD31) & $\begin{array}{l}\text { PfEMP1 (DBL2 } \delta) \\
\text { (CIDR1) }\end{array}$ & Uncommon target of binding & $\begin{array}{l}\text { (Treutiger et al. 1997, } \\
\text { Chen et al. 2000) }\end{array}$ \\
\hline CD36 & Sequestrin & Binding is questioned & (Ockenhouse et al. 1991) \\
\hline CD36/TSP & Pfalhesin & $\begin{array}{l}\text { Ligands are fragments of a } \\
\text { modified Band } 3\end{array}$ & $\begin{array}{l}\text { (Crandall et al. 1993, 1994, } \\
\text { Eda et al. 1999) }\end{array}$ \\
\hline CD36 & CLAG & $\begin{array}{l}\text { Knockout of } \operatorname{clag} 9 \text { gene } \\
\text { inhibits this adhesion }\end{array}$ & $\begin{array}{l}\text { (Holt et al. 1999, } \\
\text { Trenholme et al. 2000) }\end{array}$ \\
\hline$?$ & Pf60 & $\begin{array}{l}\text { C-terminal exon } 7 \text { of } p f 60 \text { genes } \\
\text { present high homology with } \\
\text { exon II of var genes }\end{array}$ & $\begin{array}{l}\text { (Carcy et al. 1994, } \\
\text { Bonnefoy et al. 1997, } \\
\text { Bischoff et al. 2000) }\end{array}$ \\
\hline$?$ & Pf332 & $\begin{array}{l}\text { Obscure participation in } \\
\text { cytoadherence }\end{array}$ & $\begin{array}{l}\text { (Mattei and Scherf 1992, } \\
\text { Iqbal et al. 1993, } \\
\text { Ahlborg et al. 1995) }\end{array}$ \\
\hline$?$ & STEVOR & $\begin{array}{l}\text { Could mediate cytoadherence in } \\
\text { sequestered gametocytes }\end{array}$ & $\begin{array}{l}\text { (Limpaiboon et al. 1990, } \\
\text { Cheng et al. 1998; rev. in } \\
\text { Blythe et al. 2004) }\end{array}$ \\
\hline
\end{tabular}


malaria (Berendt et al. 1989, Fernandez-Reyes et al. 1997).

Endothelial leukocyte adhesion molecule 1 (ELAM-1 or E-selectin) and vascular cell adhesion molecule 1 (VCAM-1) have been identified as potential receptors for sequestration of infected erythrocytes (Ockenhouse et al. 1992). These molecules are not expressed constitutively on endothelial cells but can be induced by IL-1 and TNF$\alpha$. The parasite ligand responsible for adhesion remains unclear. Association of clinical syndromes and adhesion to these receptors was not found in clinical isolates (Udomsangpetch et al. 1996, Newbold et al. 1997b).

Interaction of infected erythrocytes with $\mathrm{P}$ selectin occurs via the lectin domain and is $\mathrm{Ca}^{2+}$ dependent. The binding residue in infected erythrocyte is a trypsin sensitive, sialic acid, suggesting that the ligand could be part of PfEMP1 that interacts with CD36 and ICAM-1, and not CSA that is trypsin resistant (Ho et al. 1998). No study of adhesion and clinical disease has been published with this receptor.

Two other receptors are important for the binding of infected erythrocytes to the placenta. Chondroitin-4-sulfate (CSA), a glycosaminoglycan (Rogerson et al. 1995), is the main molecule involved (Fried and Duffy 1996) and uses PfEMP1 domains as ligands (DBL3, Buffet et al. 1999, CIDR, Reeder et al. 1999). The adhesion is strongly dependent on 4-O sulfation of the saccharide chains (Beeson et al. 1998). Hyaluronic acid (HA) is another receptor important for sequestration in the placenta (Beeson et al. 2000). Infected erythrocytes with dual specificity for association with these two receptors are commonly found.

Heparan sulfate (HS) has been confirmed as a host receptor, mediating cytoadherence to endothelium cells and the aorta via PfEMP1 (Barragan et al. 2000b). Recently, it has been shown that this binding is mediated by the DBL1 $\alpha$ domain (Vogt et al. 2003).

Platelet-endothelial cell adhesion molecule 1 (PECAM-1 or CD31) is involved in cytoadherence of field isolates and uses PfEMP1 as a ligand (Treutiger et al. 1997). The analysis of PECAM-1 polymorphism in malaria patients revealed that the frequency of one genotype was a risk factor for cerebral malaria (Kikuchi et al. 2001).

Another endothelial receptor with a little investigated function during infection is alpha (v) beta3. It is an integrin and is involved in many pathological and physiological processes of adherence. The ability of infected erythrocytes to adhere to alpha (v) beta3 in endothelial cells was shown to be 7-270 times larger than for uninfected erythrocytes and the binding was inhibited by anti-alpha (v) antibodies (Siano et al. 1998).

The data reviewed above clearly indicates that wild isolates have a plethora of different host receptors to cytoadhere. However, field studies have demonstrated that there are pronounced differences in the host receptor specificity and extent of cytoadherence. Thus, in spite of the binding of CD36 and TSP to almost all parasites from infected patients (Hasler et al. 1990), CD36 is quantitatively the most important receptor and ICAM-1 the second, adhering to $80 \%$ of the isolates. In contrast, minimal or no adhesion to E-selectin, VCAM-1 or CSA, has been found in most isolates (rev. in Newbold et al. 1999). Similar results were obtained in Brazilian isolates using in vitro cytoadhesion assays (Nogueira et al. 2002). Moreover, despite the fact that CSA had been associated with malaria complications during pregnancy and ICAM-1 is thought to have important role in cerebral malaria, some authors failed in the attempt to correlate binding to a certain receptor with specific syndromes caused by malaria (Marsh et al. 1988, Ho et al. 1991). These differences in the host receptor specificity and extent of cytoadherence provide a scenario where different receptors can act synergically to determine the final pattern of adhesion (McCormick et al. 1997).

Parasite Ligands Implicated in CytoADHERENCE

In addition to PfEMP1 (see below), other parasite proteins located on the surface of infected erythro- 
cytes also participate in cytoadherence (Table II).

The clag (cytoadherence-linked asexual gene) genes are a multigene family containing 9 genes located on several chromosomes (Holt et al. 1999). Clag9 is approximately $7 \mathrm{~kb}$, and predicted to be composed of 9 exons. It is located on chromosome 9 , is transcribed in mature parasites and is translated into a $220 \mathrm{kDa}$ protein. The precise cellular localization of the protein remains to be determined, however, using structural prediction, four transmembrane domains were found, suggesting the protein is exposed on the membrane of infected erythrocytes. Other evidence such as immunofluorescence, the fact that knockout of the clag9 gene inhibits adhesion of infected erythrocytes to CD36 (Trenholme et al. 2000) and transfection with antisense technology indicate that CLAG proteins are indeed ligands of CD36 (Gardiner et al. 2000).

Pf60 was first identified as a multigene family (Carcy et al. 1994) containing approximately 140 genes; primary structure from one gene of this family was reported afterwards and demonstrated that it was constitutively expressed in all mature parasites and encoded a protein located in the nucleus (Bischoff et al. 2000). The N-terminal domain does not present homology with any protein previously described. In contrast, the C-terminal exon 7 presents high homology with exon II of var genes suggesting a role in cytoadherence (Bonnefoy et al. 1997).

Pf332 is a megadalton protein which is specifically expressed in mature, asexual, blood stage parasites, is translocated from the parasite to the surface of infected red blood cells and is present in all strains with marked polymorphism (Mattei and Scherf 1992). Monoclonal antibodies against Pf332 inhibit cytoadhesion in vitro in a strain independent way (Iqbal et al. 1993), while polyclonal antibodies against Pf332 inhibit growth of the parasite but not cytoadherence (Ahlborg et al. 1995). Unfortunately, its direct role in cytoadherence remains obscure.

Sequestrin is a $270 \mathrm{kDa}$ protein identified by the use of antibodies that mimic CD36 adhesion
(Ockenhouse et al. 1991); direct prove of this interaction however, is presently lacking.

Pfalhesin, a form of the Band 3 protein modified by the parasite, was also considered as a ligand in cytoadherence to CD36 and TSP. The binding of infected erythrocytes to TSP occurs via the T3 domain and is mediated by the peptide sequence HPLQKTY of the Band 3 protein (Eda et al. 1999).

The stevor genes (subtelomeric variant open reading frame), previously reported as $7 h 8$ (Limpaiboon et al. 1990), seem unique to P. falciparum. They belong to a multigene family with 30-40 members located in the subtelomeric regions of all chromosomes (rev. in Blythe et al. 2004). stevor genes have 2 exons. Exon 1 is short and codifies an initiation codon and a transmembrane domain. The second exon $(\sim 1 \mathrm{~kb})$ codifies $30 \mathrm{kDa}$ of the protein and includes two transmembrane segments (Cheng et al. 1998). The transcription of some stevor genes is restricted to 22-32 hours post invasion (Kaviratne et al. 2002). STEVOR proteins are transported to the Maurer's clefts and located in the sub membrane of the erythrocyte. Furthermore, these proteins are also expressed in sequestered gametocytes where no PfEMP1 is detected; thus, it is speculated that STEVOR proteins could be mediating cytoadherence (rev. in Blythe et al. 2004).

\section{MOLECULAR ASPECTS OF SEVERE MALARIA}

\section{RosetTING}

Rosetting signifies the formation of rosettes due to adhesion of erythrocytes infected with mature forms of the parasite to uninfected erythrocytes (David et al. 1988, Udomsangpetch et al. 1989). Rosettes usually appear with some uninfected erythrocytes linked to one or two infected cells although this number can be much higher (Figure 2). Although rosetting has been described in other Plasmodium species that undergo sequestration, such as $P$. chabaudi, $P$. fragile and P. coatneyi (Udomsangpetch et al. 1991), it has also been found in other species, like P. vivax, $P$. ovale and P. malariae, whose mature forms develop in the outlying circulation and do not usually 
cause severe disease (Udomsangpetch et al. 1995, Angus et al. 1996, Lowe et al. 1998). In P. falciparum malaria, rosetting seems to increase microvascular obstruction of the blood flow (Kaul et al. 1991) and, according to most studies (MacPherson et al. 1985, Aikawa 1988, Carlson et al. 1990, Pongponratn et al. 1991, Treutiger et al. 1992, Ringwald et al. 1993, Reeder et al. 1994, Rowe et al. 1995, Newbold et al. 1997a, Kun et al. 1998, Heddini et al. 2001), though no all (al-Yaman et al. 1995, Traore et al. 2000), is common in patients with severe or complicated malaria.

Possibly, rosetting allows the parasite to invade uninfected erythrocytes more quickly (Wahlgren et al. 1992), but this has not been confirmed (Clough et al. 1998b). Moreover, rosetting can hide the infected cell thereby protecting it from phagocytosis, one of the main mechanisms of anti-parasitic immunity (Bouharoun-Tayoun et al. 1995).

Rosetting is widely distributed, existing in parasites from all the main malaria areas in the world, with reports in Latin America, Asia and Africa (Wahlgren et al. 1990). The stability of rosetting during in vitro cultivation varies, but the rosetting rate frequently decreases after continuous culture (Wahlgren et al. 1994).

\section{Host Receptors IMPLICATED IN ROSETTING}

Several binding combinations exist between different host receptors and parasite ligands that can induce rosette formation (Table III).

Oligosaccharides of the $\mathrm{ABO}$ blood group were the first host receptors identified in the rosetting process, mainly the blood group A antigens (Carlson and Wahlgren 1992, Barragan et al. 2000a). Binding probably occurs via PfEMP1, however antigens seem to influence only the size of the rosettes rather than the rosetting frequency.

Another receptor that may be involved in rosetting via PfEMP1 is CD36 (Handunnetti et al. 1992); yet, CD36 is present in low levels in mature erythrocytes and thus only rarely participates in rosetting (Wahlgren et al. 1992).

Immunoglobulins in normal serum, mainly
IgM, also have a function in rosetting of some strains of parasites, via PfEMP1 (Scholander et al. 1996, Clough et al. 1998a), possibly stabilizing the interaction between infected and uninfected erythrocytes (Treutiger et al. 1999).

Complement receptor 1 (CR1, CD35, C3b/C4b receptor) is a molecule expressed on the surface of erythrocytes and presents an immune regulatory role. CR1 binds to the activated complement components $\mathrm{C} 3 \mathrm{~b}$ and $\mathrm{C} 4 \mathrm{~b}$, and therefore participates in several functions such as clearance of immune complexes from the circulation, an increase in phagocytosis and regulation of complement activation (rev. in Ahearn and Fearon 1989). Rosettes can be formed by the binding of CR1 of uninfected erythrocytes to PfEMP1 of some laboratory-adapted parasite strains (Rowe et al. 1997). Presently, the only PfEMP1 domain implicated in rosetting is DBL1, mediating adhesion to uninfected erythrocytes by CR1 (Rowe et al. 1997, 2000) or glycosaminoglycans (GAG), like HS of the erythrocytes (Chen et al. 1998a). Moreover, it was demonstrated that a PfEMP1 soluble area $(\mathrm{DBL} 1 \alpha)$ requires a minimum fragment of heparin 12-mers (approximately $4 \mathrm{kDa}$ ) for adhesion and this fragment is able to separate naturally formed rosettes (Barragan et al. 2000b).

\section{PARASITE LIGANDS IMPLICATED IN RosetTING}

Besides PfEMP1 (see below), one other molecule seem to be involved in rosetting: RIFINS or rosettins. RIFINs or rosettins are highly polymorphic proteins from 20 to $40 \mathrm{kDa}$ encoded by a multigene family composed of 200 members, denominated rif, repetitive interspersed family (Weber 1988, Helmby et al. 1993). The rifgenes are composed of one short 5' exon, that encodes a signal peptide, a short intron and another exon of $\sim 1.3 \mathrm{~kb}$. rif genes are clustered with var genes in the subtelomeric regions of chromosomes (Kyes et al. 1999), are transcribed in the asexual stages and the products are exported to the surface of the infected erythrocyte, where they can be detected from 14 to 16 hours after invasion. Many RIFINs can be expressed on the surface of erythrocytes infected with only one parasite, conferring 
TABLE III

Host receptors and parasite ligands involved in rosetting. Host receptors: CD36 (cluster of differentiation 36), IgM (immunoglobulin M), CR1 (complement receptor 1), GAG (glycosaminoglycans). Parasite ligands: PfEMP1 (P. falciparum erythrocyte membrane protein 1). Domains: DBL (Duffy binding-like), CIDR (cysteine rich interdomain region). HS (heparan sulfate).

\begin{tabular}{l|l|l|l}
\hline $\begin{array}{l}\text { Host receptors } \\
\text { (synonymous) }\end{array}$ & $\begin{array}{l}\text { Parasite ligands } \\
\text { (domain) }\end{array}$ & $\begin{array}{l}\text { Relevant remarks } \\
\text { of each interaction }\end{array}$ & References \\
\hline ABO Antigens & PfEMP1 (DBL1 $\alpha)$ & Blood group A & $\begin{array}{l}\text { (Carlson and Wahlgren 1992, } \\
\text { Barragan et al. 2000a) }\end{array}$ \\
\hline CD36 & PfEMP1 & $\begin{array}{l}\text { Low levels of CD36 in mature } \\
\text { erythrocytes }\end{array}$ & $\begin{array}{l}\text { (Handunnetti et al. 1992, } \\
\text { Wahlgren et al. 1992) }\end{array}$ \\
\hline IgM & $\begin{array}{l}\text { PfEMP1 (CIDR1 } \alpha) \\
\text { (DBL2 } \beta)\end{array}$ & $\begin{array}{l}\text { (Scholander et al. 1996, Clough et } \\
\text { al. 1998a, Treutiger et al. 1999) }\end{array}$ \\
\hline CR1 (CD35) & PfEMP1 (DBL1 $\alpha)$ & Polymorphism of CD35 in Africans & (Rowe et al. 1997, 2000) \\
\hline GAG & PfEMP1 (DBL1 $\alpha)$ & HS in erythrocytes & (Chen et al. 1998a) \\
\hline$?$ & Rosettins (Rifins) & Poorly defined & $\begin{array}{l}\text { (Weber 1988, Helmby et al. 1993, } \\
\text { Kyes et al. 1999, Fernandez et al. 1999) }\end{array}$ \\
\hline
\end{tabular}

great antigenic variability. The function of RIFINs has not been established but they are thought to be CD31 and rosetting ligands (Fernandez et al. 1999, Kyes et al. 1999). However, their main function seems to be related to antigenic variation.

\section{ANTIGENIC VARIATION}

Most of the Plasmodium life cycle in the vertebrate host occurs in erythrocytes and is necessary for the infection of mosquitoes and parasite survival. As mature erythrocytes do not differ phenotypically, do not contain internal mechanisms of synthesis or traffic of proteins and do not express class I or II MHC molecules on their surface, they represent an ideal atmosphere for the parasite to hide from the immune system of the host. However, Plasmodium synthesizes proteins that cross the parasite plasma membrane, the membrane of the parasitophorous vacuole and are inserted into the erythrocyte surface. After 18 hours of invasion by $P$. falciparum, these surface antigens mediate adhesion to several receptors of the host endothelium, preventing the infected erythrocytes from passing through the spleen, where they would be destroyed. In doing so however, the erythrocyte surface proteins make the parasite "visi- ble" to the host immune system and thus the parasite needs to vary the proteins to avoid destruction (rev. in Newbold 1999). Of notice, in vitro studies with $P$. falciparum clones verified that the rate of antigenic switching of a certain variant is around $2 \%$ per generation (Biggs et al. 1991, Roberts et al. 1992) (Figure 3). However, mathematical modeling predicts rates substantially slower $(0.03 \%$ per generation) (Paget-McNicol et al. 2002) or faster (18\%) (Gatton et al. 2003).

Antigenic variation was first described in $P$. knowlesi with the observation of the immune response in chronic infection of primates (Brown and Brown 1965). Later, it was described in P. falciparum (Langreth and Reese 1979), P. fragile (Handunnetti et al. 1987), P. chabaudi (McLean et al. 1982), and has been suggested in P. vivax (Mendis et al. 1988, del Portillo et al. 2001). The variant antigen of $P$. knowlesi responsible for antigenic variation on the surface of infected erythrocytes was identified in 1983 (Howard et al. 1983). One year later, the same group identified the homologous antigen for $P$. falciparum, which is strain-specific, has $\sim 280 \mathrm{kDa}$, and was named Plasmodium falciparum Erythrocyte Membrane Protein 1 (PfEMP1) (Leech et al. 1984). 


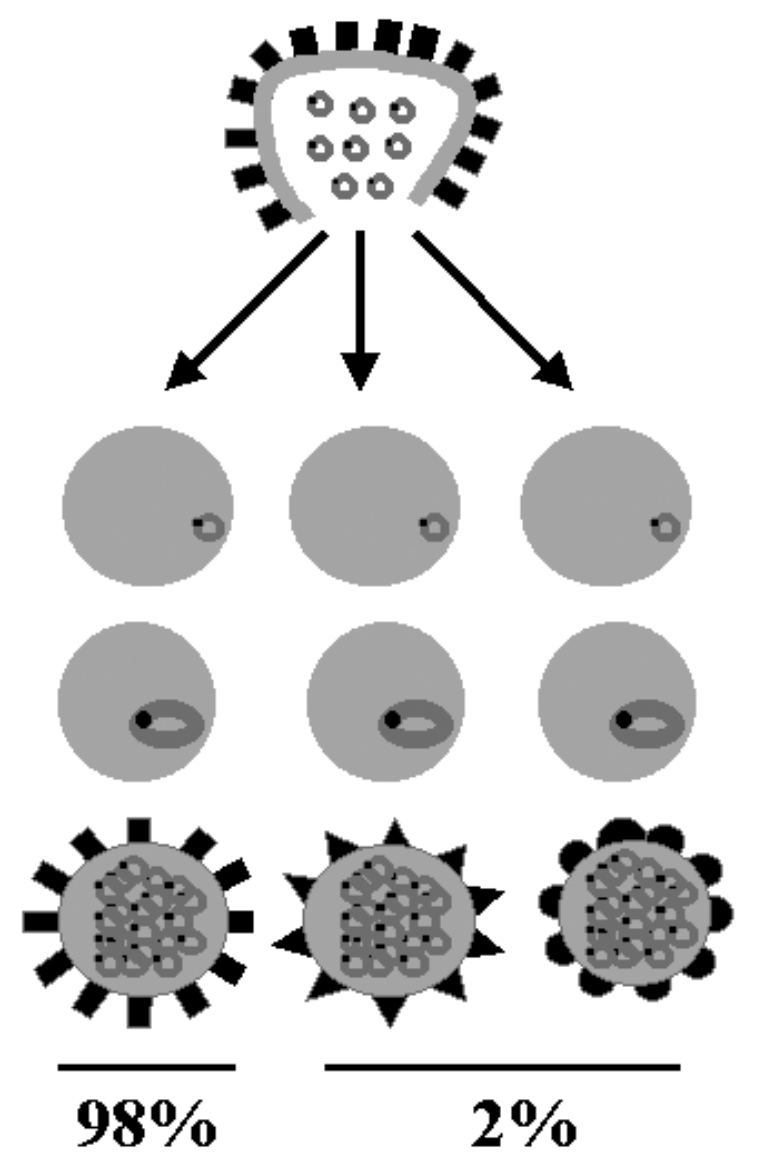

Fig. 3 - Schematic representation of PfEMP1 protein switching. Merozoites released from a burst infected red blood cell expressing a particular PfEMP1 phenotype (squares), invade new erythrocytes which after completion of the asexual blood cycle give rise to schizonts expressing the original PfEMP1 phenotype in $98 \%$ of the erythrocytic population; remaining erythrocytes express different phenotypes at a rate of 2\% (Biggs et al. 1991,

Roberts et al. 1992).

Erythrocyte Membrane Protein i (PfEMPi) AND var GENES

PfEMP1 is encoded by var genes (Baruch et al. 1995, Smith et al. 1995, Su et al. 1995). var genes are present in multiple copies comprising a gene family with approximately 60 copies per haploid genome. They are located in the subtelomeric regions of all 14 chromosomes (at least 1 gene per telomere) in any orientation and in internal clusters on chromosomes 4, 7, 8 and 12 (Rubio et al. 1996, Thompson et al. 1997, Fischer et al. 1997, Gardner et al. 2002). The telomeric location is not a prerequisite for var gene expression, but has been postulated to be important for the generation of diversity, together with mutation, insertion and deletion events (Hernandez-Rivas et al. 1997, Ward et al. 1999, Taylor et al. 2000). Indeed, frequent ectopic recombination facilitating gene conversion has been demonstrated in var genes and occurs in the subtelomeric regions of heterologous chromosomes (Freitas-Junior et al. 2000).

Control of var gene expression is not yet well understood and there are different views with regard to their expression. Thus, some groups believe that several var genes are transcribed during the ring stages and as the parasite matures only one var gene is expressed in mature trophozoites $(\sim 16$ hours) where only one full-length mRNA message is detected (Rowe et al. 1997, Scherf et al. 1998, Chen et al. 1998b). Yet, other group raises the possibility that there is complete transcription of many var genes in trophozoite stages and that there is selective and rapid 3' to 5' degradation of the products not destined for expression (Taylor et al. 2000). Analysis of synchronized mature parasites selected for a certain receptor (a phenotypically homogeneous population) demonstrated that multiple full-length var genes transcripts could be detected (Noviyanti et al. 2001). Moreover, a monoclonal antibody against the ATS region was also able to detect several bands in extracts of these parasites, although a dominant PfEMP1 was always observed, probably determining the adhesion phenotype. Last, analysis of individual cells confirmed the transcription of multiple var genes by a parasite in the trophozoite-stage (Duffy et al. 2002). Regardless of whether only one full-length as opposed to several full-length var mRNA messages is/are present in mature asexual blood stages, it is a consensus that there is clonal expression of PfEMP1 proteins displaying different adhesive phenotypes by individually infected erythrocytes.

var genes are organized in two exons, with a total size ranging from 6 to $13 \mathrm{~kb}$, excluding the $1 \mathrm{~kb}$ intron (Su et al. 1995, rev. in Smith et al. 2001) (Figure 4). Exon $2(1.6 \mathrm{~kb})$ codifies an acidic terminal 


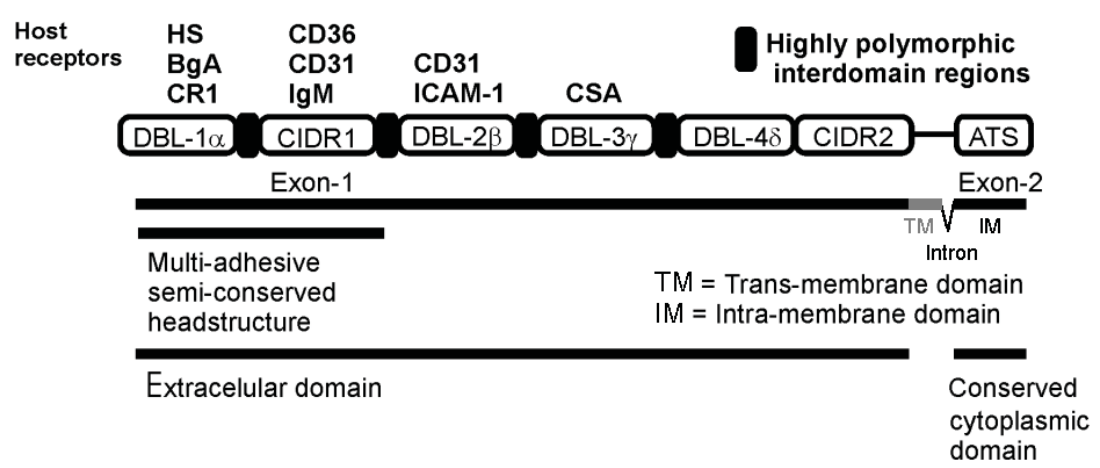

Fig. 4 - Schematic representation of the PfEMP1 structure showing host receptors and domains (http://sites.huji.ac.il/malaria/maps/PfEMP1.html). Host receptors: HS (heparan sulfate), BgA (Blood group A), CR1 (complement receptor 1), CD36 (cluster of differentiation 36), CD31 (cluster of differentiation 31), IgM (immunoglobulin M), ICAM 1 (intercellular adhesion molecule 1), CSA (chondroitin4-sulfate). PfEMP1 domains: DBL (Duffy binding-like), CIDR (cysteine rich interdomain region), ATS (acidic terminal segment). Structure of the var genes (exon 1, intron, exon 2) is shown below PfEMP1.

segment (ATS), an intracellular domain, involved in the anchoring of PfEMP1 to host proteins (spectrin and actin from the erythrocyte skeleton) or parasite proteins (KAHRP, knob-associated histidinerich protein), located in the knob (Oh et al. 2000). Exon $1(4-10 \mathrm{~kb})$ encodes a transmembrane region and the region that is exposed on the surface of the infected erythrocyte. The extracellular region presents from 2 to 7 highly polymorphic domains, denominated DBLs (Duffy binding like domains), and one or two low polymorphic regions rich in cysteines (CIDR, cysteine rich interdomain region), exclusive to $P$. falciparum. DBLs are homologous to P. falciparum erythrocyte binding antigens (EBAs) and to $P$. vivax and P. knowlesi Duffy antigen binding proteins involved in the invasion of the erythrocyte and binding to their proteins, such as Duffy and glycophorin A (Adams et al. 1992, Sim et al. 1994). DBLs in PfEMP1 and in EBA present 10 conserved cysteines that are distributed in 10 blocks. DBLs and CIDRs are identified by the position of the domain in the gene (DBL1-7; CIDR1 or 2) and the Greek letter indicates the homology groups (DBLs: $\alpha, \beta, \gamma, \delta$ and $\varepsilon$; CIDRs: $\alpha, \beta$ and $\gamma$ ). Among all DBL domains in PfEMP1, DBL1 $\alpha$ is the more conserved and consequently has been a target for studies of var gene repertories in many parts or the world (Kyes et al. 1997, Ward et al. 1999, Kirchgatter et al. 2000). These studies revealed that similarity of DBL1 $\alpha$ var sequences is not a predictor of geographic origin.

The structure and organization of the domains from 20 PfEMP1 were determined (Smith et al. $2000 \mathrm{~b})$. The authors were able to verify associations of domains such as DBL $\alpha, \operatorname{DBL} \beta, \operatorname{DBL} \delta$, with $\mathrm{CIDR} \alpha, \mathrm{C} 2, \mathrm{CIDR} \beta$, respectively. Moreover, two new domain-like conserved regions were also identified and were located in the extracellular part of the molecule. The first is an $\mathrm{N}$-terminal segment (NTS), theoretically globular, that, starting from the methionine initiator residue, can have from 75 to 107 amino acids. NTS does not present homology with any sequence in the databases, but probably has a central $\alpha$-helix. The second, from 140 to 217 amino acids, was designated $\mathrm{C} 2$ and is not present in all of the analyzed sequences but, like the NTS region, is supposedly globular, has an $\alpha$-helix structure and a unique sequence.

The data on expression of var genes, PfEMP1 proteins and structural organization of PfEMP1 clearly indicates that the increase in expression of a non-dominant gene and its corresponding PfEMP1 variant can facilitate a switch in the adhesion phenotype leading to variants that can be associated to dif- 
ferent clinical syndromes including severe malaria.

\section{Severe Malaria and PfEMPi Genotype}

Few studies have reported associations of severe malaria and particular PfEMP1 protein sequences. Thus, a study on a hypoendemic area of French Guyana involving 19 severe malaria patients demonstrated that there was a particular DBL $\delta$ var sequence expressed exclusively by these patients as opposed to 32 patients with mild malaria (Ariey et al. 2001). Similar results were obtained in Brazil where parasites from patients with severe malaria transcribed predominantly DBL1 $\alpha$ var sequences lacking 1-2 cysteine residues, while parasites from patients with mild malaria transcribed preferentially DBL1 $\alpha$ var sequences without these deletions (Kirchgatter and del Portillo 2002). Recently, it was shown that $P$. falciparum strains associated with severe malaria preferentially express PfEMP1 encoded by group A var genes, which are transcribed towards the telomere (Jensen et al. 2004). These data indicate that there are indeed associations between severe malaria and particular PfEMP1 sequences. However, these studies are complicated by the extensive variation and simultaneous transcription of var genes and technical difficulties such as primer bias. Moreover, as cited here, in addition to the var multigene family, other multigene families such as rif, stevor, clag, and Pf60, likely to be involved in virulence, were described in $P$. falciparum. To further complicate matters, the phenotype transcribed by circulating parasites may be different to those sequestered (Duffy et al. 2002). High throughput methodologies can now be envisaged to discover and compare the repertoire of genomic and expressed virulence genes circulating in endemic regions with particular clinical syndromes of severe malaria to pursue the development of PfEMP1based malaria vaccines.

\section{PfEMPi VACCINES}

It is amply accepted that acquired immunity in malaria is developed after continuous exposure of patients to different isolates expressing highly vari- ant surface antigens, mainly PfEMP1, and that antibodies against them play a major role in this acquisition. Indeed, the presence of anti-PfEMP1 antibodies has been associated with the development of clinical immunity (David et al. 1983, Reeder and Brown 1996, Bull et al. 1998, Barragan et al. 1998, Giha et al. 1999, Bull et al. 1999, Giha et al. 2000). Immune responses against PfEMP1 however, are variant-specific (Newbold et al. 1992). Thus, individuals with low exposure to $P$. falciparum show limited recognition of the surface of the infected erythrocyte (Marsh and Howard 1986, Bull et al. 1998), whereas sera from adults resident in endemic areas can agglutinate infected erythrocytes from different strains and isolates (Aguiar et al. 1992, Reeder et al. 1994). This data indicates that a vaccine against variant-specific PfEMP1 epitopes might be unrealistic; yet, the use of relatively conserved PfEMP1 domains or new vaccine strategies to generate crossreacting antibodies may circumvent this problem.

The CIDR1 domain of PfEMP1 is a relatively conserved domain (Smith et al. 2000b). Of importance, in spite of CIDR1 domain being unable to induce high antibody titers during infection (Baruch et al. 1996, 1997), monoclonal antibodies produced against different regions of this domain reacted with several strains, expressing different PfEMP1 variants (Gamain et al. 2001). Moreover, a monoclonal antibody was capable of recognizing $90 \%$ of the strains tested, only failing to react with those that do not bind to CD36. Furthermore, some immunization experiments accomplished in monkeys using a 179-amino acid region of the CIDR 1 domain, induced protection against a lethal strain (Baruch et al. 2002). More recently, induction of crossreactive antibodies was also obtained after immunization of mice with three different CIDR1 that have critical function of binding to CD36 (Gratepanche et al. 2003). Thus, CIDR $1 \alpha$-based general malaria vaccines have served the proof-of-principle of the possibilities of developing vaccines against variant antigens and other PfEMP1 domains are also being exploited for this purpose (Lekana-Douki et al. 2002, Chen et al. 2004). 


\section{PERSPECTIVES}

The pathogenesis of falciparum malaria involves complex interactions of host and parasite factors further complicated by the fact that antigenic and adhesive properties of circulating parasites may be quite different to those sequestered. The complete sequences of the human and Plasmodium falciparum genomes, high-throughput methodologies and reverse genetics, along with clinical data from different epidemiological regions, will hopefully lead to a better understanding of the role of these complex interactions in different clinical syndromes of human malaria and to new opportunities for interventions to treat or prevent severe malaria.

\section{RESUMO}

O ciclo eritrocítico do Plasmodium falciparum apresenta uma particularidade em relação às outras espécies de Plasmodium que infectam o homem. Trofozoítas maduros e esquizontes são seqüestrados da circulação periférica devido à adesão de eritrócitos infectados às células endoteliais. Modificações na superfície dos eritrócitos infectados, denominadas "knobs", permitem adesão ao endotélio e a outros eritrócitos. A adesão fornece uma melhor maturação na atmosfera venosa microaerofílica e permite que o parasita escape do clareamento pelo baço, que reconhece a perda de deformabilidade do eritrócito infectado. A adesão ao endotélio ou citoaderência, tem importante função na patogenicidade da doença, causando obstrução de pequenos vasos e contribuindo para danos em muitos órgãos. Citoaderência designa também a adesão de eritrócitos infectados a eritrócitos não infectados, fenômeno amplamente conhecido como "rosetting". Aspectos clínicos da malária grave bem como receptores do hospedeiro e ligantes do parasita envolvidos em citoaderência e "rosetting", são revisados aqui. A proteína de membrana do eritrócito 1 de $P$. falciparum (PfEMP1) parece ser o principal ligante adesivo dos eritrócitos infectados e será discutida em maiores detalhes. Uma melhor compreensão da função dos receptores do hospedeiro e dos ligantes do parasita no desenvolvimento de diferentes síndromes clínicas é urgentemente necessária para identificar alvos para vacinação visando diminuir as taxas de mortalidade desta doença.
Palavras-chave: malária grave, Plasmodium falciparum, PfEMP1, patogênese, citoaderência, "rosetting", variação antigênica.

\section{REFERENCES}

Adams JH, Sim BK, Dolan SA, Fang X, Kaslow DC AND MiLLER LH. 1992. A family of erythrocyte binding proteins of malaria parasites. Proc Natl Acad Sci USA 89: 7085-7089.

Aguiar JC et Al. 1992. Agglutination of Plasmodium falciparum-infected erythrocytes from east and west African isolates by human sera from distant geographic regions. Am J Trop Med Hyg 47: 621-632.

AHEARn JM and FEARon DT. 1989. Structure and function of the complement receptors, CR1 (CD35) and CR2 (CD21). Adv Immunol 46: 183-219.

Ahlborg N, Iqbal J, Hansson M, Uhlen M, Mattei D, Perlmann P, Stahl S and Berzins K. 1995. Immunogens containing sequences from antigen Pf332 induce Plasmodium falciparum-reactive antibodies which inhibit parasite growth but not cytoadherence. Parasite Immunol 17: 341-352.

AIKAwA M. 1988. Human cerebral malaria. Am J Trop Med Hyg 39: 3-10.

al-Yaman F, Genton B, Mokela D, Raiko A, Kati S, Rogerson S, ReEder J ANd Alpers M. 1995. Human cerebral malaria: lack of significant association between erythrocyte rosetting and disease severity. Trans R Soc Trop Med Hyg 89: 55-58.

Angus BJ, Thanikkul K, Silamut K, White NJ and UdomsangPetch R. 1996. Short report: Rosette formation in Plasmodium ovale infection. Am J Trop Med Hyg 55: 560-561.

Ariey F, Hommel D, Le Scanf C, Duchemin JB, Peneau C, Hulin A, Sarthou JL, Reynes JM, FanDeur T and Mercereau-Puijalon O. 2001. Association of severe malaria with a specific Plasmodium falciparum genotype in French Guiana. J Infect Dis 184: $237-241$

Assicot M, Gendrel D, Carsin H, Raymond J, GuilBAUD J AND BoHUON C. 1993. High serum procalcitonin concentrations in patients with sepsis and infection. Lancet 341: 515-518.

Barnwell JW, Asch AS, Nachman RL, Yamaya M, AiKaWA M AND IngRaVAllo P. 1989. A human 88- 
$\mathrm{kD}$ membrane glycoprotein (CD36) functions in vitro as a receptor for a cytoadherence ligand on Plasmodium falciparum-infected erythrocytes. J Clin Invest 84: 765-772.

Barragan A, Kremsner PG, Weiss W, Wahlgren M AND CARLson J. 1998. Age-related buildup of humoral immunity against epitopes for rosette formation and agglutination in African areas of malaria endemicity. Infect Immun 66: 4783-4787.

Barragan A, Kremsner PG, Wahlgren M And CARlSON J. 2000a. Blood group A antigen is a coreceptor in Plasmodium falciparum rosetting. Infect Immun 68: 2971-2975.

Barragan A, Fernandez V, Chen Q, von Euler A, Wahlgren M and SpIllmann D. 2000b. The duffy-binding-like domain 1 of Plasmodium falciparum erythrocyte membrane protein 1 (PfEMP1) is a heparan sulfate ligand that requires 12 mers for binding. Blood 95: 3594-3599.

Baruch DI, Pasloske BL, Singh HB, Bi X, Ma XC, Feldman M, Taraschi TF and Howard RJ. 1995. Cloning the $P$. falciparum gene encoding PfEMP1, a malarial variant antigen and adherence receptor on the surface of parasitized human erythrocytes. Cell 82: 77-87.

Baruch DI, Gormely JA, Ma C, Howard RJ AND PAsloske BL. 1996. Plasmodium falciparum erythrocyte membrane protein 1 is a parasitized erythrocyte receptor for adherence to CD36, thrombospondin, and intercellular adhesion molecule 1. Proc Natl Acad Sci USA 93: 3497-3502.

Baruch DI, Ma XC, Singh HB, Bi X, Pasloske BL AND HowARD RJ. 1997. Identification of a region of PfEMP1 that mediates adherence of Plasmodium falciparum infected erythrocytes to CD36: conserved function with variant sequence. Blood 90: 3766-3775.

Baruch DI, Gamain B, Barnwell JW, Sullivan JS, Stowers A, Galland GG, Miller LH and Collins WE. 2002. Immunization of Aotus monkeys with a functional domain of the Plasmodium falciparum variant antigen induces protection against a lethal parasite line. Proc Natl Acad Sci USA 99: 3860-3865.

Beeson JG, Chai W, Rogerson SJ, Lawson AM and Brown GV. 1998. Inhibition of binding of malaria- infected erythrocytes by a tetradecasaccharide fraction from chondroitin sulfate A. Infect Immun 66: 3397-3402.

Beeson JG, Rogerson SJ, Cooke BM, Reeder JC, Chai W, Lawson AM, Molyneux ME and Brown GV. 2000. Adhesion of Plasmodium falciparum-infected erythrocytes to hyaluronic acid in placental malaria. Nat Med 6: 86-90.

Berendt AR, Simmons DL, TANSEy J, Newbold CI AND MARSH K. 1989. Intercellular adhesion molecule-1 is an endothelial cell adhesion receptor for Plasmodium falciparum. Nature 341: 57-59.

Berendt AR, McDowall A, Craig AG, Bates PA, Sternberg MJ, Marsh K, Newbold CI ANd HogG N. 1992. The binding site on ICAM-1 for Plasmodium falciparum-infected erythrocytes overlaps, but is distinct from, the LFA-1-binding site. Cell 68: 71-81.

Biggs BA, Gooze L, Wycherley K, Wollish W, Southwell B, Leech JH ANd Brown GV. 1991. Antigenic variation in Plasmodium falciparum. Proc Natl Acad Sci USA 88: 9171-9174.

Bignami A and Bastianelli A. 1889. Observation of estivo-autumnal malaria. Riforma Medica 6: 13341335.

Bischoff E, Guillotte M, Mercereau-Puijalon O AND Bonnefoy S. 2000. A member of the Plasmodium falciparum Pf60 multigene family codes for a nuclear protein expressed by readthrough of an internal stop codon. Mol Microbiol 35: 1005-1016.

Blythe Je, Surentheran T And Preiser PR. 2004. STEVOR-a multifunctional protein? Mol Biochem Parasitol 134: 11-15.

Bonnefoy S, Bischoff E, Guillotte M and MerceREAU-PUIJALON O. 1997. Evidence for distinct prototype sequences within the Plasmodium falciparum Pf60 multigene family. Mol Biochem Parasitol 87: $1-11$.

Bouharoun-Tayoun H, Oeuvray C, Lunel F and Druilhe P. 1995. Mechanisms underlying the monocyte-mediated antibody-dependent killing of Plasmodium falciparum asexual blood stages. J Exp Med 182: 409-418.

Boulos M. 1992. Clinical picture of severe malaria. Rev Inst Med Trop São Paulo 34 (Suppl. 9): S41-42. 
Breman JG. 2001. The ears of the hippopotamus: manifestations, determinants, and estimates of the malaria burden. Am J Trop Med Hyg 64: 1-11.

BROWN KN AND BROWN IN. 1965. Immunity to malaria: antigenic variation in chronic infections of Plasmodium knowlesi. Nature 208: 1286-1288.

Buffet PA ET AL. 1999. Plasmodium falciparum domain mediating adhesion to chondroitin sulfate A: a receptor for human placental infection. Proc Natl Acad Sci USA 96: 12743-12748.

Bull PC, Lowe BS, Kortok M, Molyneux CS, NewBOLD CI AND MARsh K. 1998. Parasite antigens on the infected red cell surface are targets for naturally acquired immunity to malaria. Nat Med 4: 358-360.

Bull PC, Lowe BS, Kortok M and Marsh K. 1999. Antibody recognition of Plasmodium falciparum erythrocyte surface antigens in Kenya: evidence for rare and prevalent variants. Infect Immun 67: 733-739.

Carcy B, Bonnefoy S, Guillotte M, Le Scanf C, Grellier P, Schrevel J, Fandeur T and MerceREAU-PuiJalon O. 1994. A large multigene family expressed during the erythrocytic schizogony of Plasmodium falciparum. Mol Biochem Parasitol 68: 221-233.

Carlson J And Wahlgren M. 1992. Plasmodium falciparum erythrocyte rosetting is mediated by promiscuous lectin-like interactions. J Exp Med 176: 1311-1317.

Carlson J, Helmby H, Hill AV, Brewster D, GreenWOOD BM AND WAHLGREN M. 1990. Human cerebral malaria: association with erythrocyte rosetting and lack of anti-rosetting antibodies. Lancet 336: 1457-1460.

Chen Q, Barragan A, Fernandez V, Sundstrom A, Schlichtherle M, Sahlen A, Carlson J, Datta S AND WAHLGREN M. 1998a. Identification of Plasmodium falciparum erythrocyte membrane protein 1 (PfEMP1) as the rosetting ligand of the malaria parasite $P$. falciparum. J Exp Med 187: 15-23.

Chen Q, Fernandez V, Sundstrom A, Schlichtherle M, Datta S, Hagblom P and WahlgRen M. 1998 b. Developmental selection of var gene expression in Plasmodium falciparum. Nature 394: 392-395.

Chen Q, Heddini A, Barragan A, Fernandez V, Pearce SF and Wahlgren M. 2000. The semiconserved head structure of Plasmodium falciparum erythrocyte membrane protein 1 mediates binding to multiple independent host receptors. J Exp Med 192: $1-10$.

Chen Q, Pettersson F, Vogt AM, Schmidt B, Ahuja S, LiLJESTROM P AND WAHLGREN M. 2004. Immunization with PfEMP1-DBL1alpha generates antibodies that disrupt rosettes and protect against the sequestration of Plasmodium falciparum-infected erythrocytes. Vaccine 22: 2701-2712.

Cheng Q, Cloonan N, Fischer K, Thompson J, Waine G, LANZer M AND Saul A. 1998. stevor and rif are Plasmodium falciparum multicopy gene families which potentially encode variant antigens. Mol Biochem Parasitol 97: 161-176.

Chiwakata CB, Manegold C, Bonicke L, WaAse I, Julch C AND Dietrich M. 2001. Procalcitonin as a parameter of disease severity and risk of mortality in patients with Plasmodium falciparum malaria. J Infect Dis 183: 1161-1164.

Clough B, Atilola FA, Black J and Pasvol G. 1998a. Plasmodium falciparum: the importance of IgM in the rosetting of parasite-infected erythrocytes. Exp Parasitol 89: 129-132.

Clough B, Atilola FA and Pasvoi G. 1998b. The role of rosetting in the multiplication of Plasmodium falciparum: rosette formation neither enhances nor targets parasite invasion into uninfected red cells. $\mathrm{Br}$ J Haematol 100: 99-104.

Cooke BM, Nicoll CL, Baruch DI AND Coppel RL. 1998. A recombinant peptide based on PfEMP-1 blocks and reverses adhesion of malaria-infected red blood cells to CD36 under flow. Mol Microbiol 30: 83-90.

Corbett CE, Duarte Mi, Lancellotti CL, Silva MA AND ANDRADE Junior HF. 1989. Cytoadherence in human falciparum malaria as a cause of respiratory distress. J Trop Med Hyg 92: 112-120.

Crandall I, Collins WE, Gysin J and Sherman IW. 1993. Synthetic peptides based on motifs present in human band 3 protein inhibit cytoadherence/sequestration of the malaria parasite Plasmodium falciparum. Proc Natl Acad Sci USA 90: 4703-4707.

Crandall I, Guthrie N, Demers D and Sherman IW. 1994. Plasmodium falciparum: CD36 dependent cytoadherence or rosetting of infected erythrocytes is modulated by knobs. Cell Adhes Commun 2: 503-510. 
David PH, Hommel M, Miller LH, Udeinya IJ AND Oligino LD. 1983. Parasite sequestration in Plasmodium falciparum malaria: spleen and antibody modulation of cytoadherence of infected erythrocytes. Proc Natl Acad Sci USA 80: 5075-5079.

David PH, Handunnetti SM, Leech JH, Gamage P AND Mendis KN. 1988. Rosetting: a new cytoadherence property of malaria-infected erythrocytes. Am J Trop Med Hyg 38: 289-297.

DEL Portillo HA ET AL. 2001. A superfamily of variant genes encoded in the subtelomeric region of Plasmodium vivax. Nature 410: 839-842.

Duarte Mi, Corbett CE, Boulos M and Amato Neto V. 1985. Ultrastructure of the lung in falciparum malaria. Am J Trop Med Hyg 34: 31-35.

Duffy MF, Brown GV, Basuki W, Krejany EO, Noviyanti R, Cowman AF And Reeder JC. 2002. Transcription of multiple var genes by individual, trophozoite-stage Plasmodium falciparum cells expressing a chondroitin sulfate A binding phenotype. Mol Microbiol 43: 1285-1293.

Eda S, Lawler J and Sherman IW. 1999. Plasmodium falciparum-infected erythrocyte adhesion to the type 3 repeat domain of thrombospondin- 1 is mediated by a modified band 3 protein. Mol Biochem Parasitol 100: 195-205.

Fernandez V, Hommel M, Chen Q, Hagblom P and WAHLGREN M. 1999. Small, clonally variant antigens expressed on the surface of the Plasmodium falciparum-infected erythrocyte are encoded by the rif gene family and are the target of human immune responses. J Exp Med 190: 1393-1404.

Fernandez-Reyes D, Craig AG, Kyes SA, Peshu N, Snow RW, Berendt AR, Marsh K And Newbold CI. 1997. A high frequency African coding polymorphism in the N-terminal domain of ICAM-1 predisposing to cerebral malaria in Kenya. Hum Mol Genet 6: $1357-1360$.

Fischer K, Horrocks P, Preuss M, Wiesner J, Wunsch S, Camargo AA and Lanzer M. 1997. Expression of var genes located within polymorphic subtelomeric domains of Plasmodium falciparum chromosomes. Mol Cell Biol 17: 3679-3686.

Freitas-Junior LH, Bottius E, Pirrit LA, Deitsch KW, Scheidig C, Guinet F, Nehrbass U, Wellems TE AND Scherf A. 2000. Frequent ectopic recombi- nation of virulence factor genes in telomeric chromosome clusters of $P$. falciparum. Nature 407: 10181022.

FrIEd M ANd Duffy PE. 1996. Adherence of Plasmodium falciparum to chondroitin sulfate $\mathrm{A}$ in the human placenta. Science 272: 1502-1504.

Gamain B, Miller LH and Baruch DI. 2001. The surface variant antigens of Plasmodium falciparum contain cross-reactive epitopes. Proc Natl Acad Sci USA 98: 2664-2669.

Gardiner DL, Holt DC, Thomas EA, Kemp DJ AND Trenholme KR. 2000. Inhibition of Plasmodium falciparum clag 9 gene function by antisense RNA. Mol Biochem Parasitol 110: 33-41.

GARDNER MJ ET AL. 2002. Genome sequence of the human malaria parasite Plasmodium falciparum. Nature 419: 498-511.

Gatton ML, Peters JM, Fowler EV and Cheng Q. 2003. Switching rates of Plasmodium falciparum var genes: faster than we thought? Trends Parasitol 19: 202-208.

Giha HA, Staalsoe T, Dodoo D, Elhassan IM, Roper C, Satti GM, Arnot DE, Theander TG and HviId L. 1999. Nine-year longitudinal study of antibodies to variant antigens on the surface of Plasmodium falciparum-infected erythrocytes. Infect Immun 67: 4092-4098.

Giha HA, Staalsoe T, Dodoo D, Roper C, Satti GM, Arnot DE, HviId L And TheAnder TG. 2000. Antibodies to variable Plasmodium falciparum-infected erythrocyte surface antigens are associated with protection from novel malaria infections. Immunol Lett 71: 117-126.

Gratepanche S, Gamain B, Smith JD, Robinson BA, Saul A ANd Miller LH. 2003. Induction of crossreactive antibodies against the Plasmodium falciparum variant protein. Proc Natl Acad Sci USA 100: 13007-13012.

Handunnetti SM, Mendis KN AND David PH. 1987. Antigenic variation of cloned Plasmodium fragile in its natural host Macaca sinica. Sequential appearance of successive variant antigenic types. J Exp Med 165: 1269-1283.

Handunnetti SM, van SchravendiJK MR, HaSler T, Barnwell JW, Greenwalt DE and Howard RJ. 1992. Involvement of CD36 on erythrocytes 
as a rosetting receptor for Plasmodium falciparuminfected erythrocytes. Blood 80: 2097-2104.

Hasler T, Handunnetti SM, Aguiar JC, van SchravendiJK MR, GReEnWoOd BM, LALlinger G, CEgIelsKi P AND HowARD RJ. 1990. In vitro rosetting, cytoadherence, and microagglutination properties of Plasmodium falciparum-infected erythrocytes from Gambian and Tanzanian patients. Blood 76: 1845-1852.

Heddini A, Pettersson F, Kai O, Shafi J, Obiero J, Chen Q, Barragan A, Wahlgren M and Marsh K. 2001. Fresh isolates from children with severe Plasmodium falciparum malaria bind to multiple receptors. Infect Immun 69: 5849-5856.

Helmby H, Cavelier L, Pettersson U and Wahlgren M. 1993. Rosetting Plasmodium falciparum-infected erythrocytes express unique strain-specific antigens on their surface. Infect Immun 61: 284-288.

Hernandez-Rivas R, Mattei D, Sterkers Y, PeterSON DS, Wellems TE AND Scherf A. 1997. Expressed var genes are found in Plasmodium falciparum subtelomeric regions. Mol Cell Biol 17: 604-611.

Ho M, Singh B, Looareesuman S, Davis TM, Bunnag D AND White NJ. 1991. Clinical correlates of in vitro Plasmodium falciparum cytoadherence. Infect Immun 59: 873-878.

Ho M, Schollaardt T, NiU X, Looareesuwan S, Patel KD and Kubes P. 1998. Characterization of Plasmodium falciparum-infected erythrocyte and P-selectin interaction under flow conditions. Blood 91: 4803-4809.

Hollenstein U, Looareesuwan S, Aichelburg A, Thalhammer F, Stoiser B, Amradee S, ChulLawichit S, El Menyawi I and Burgmann H. 1998. Serum procalcitonin levels in severe Plasmodium falciparum malaria. Am J Trop Med Hyg 59: 860-863.

Holt DC, Gardiner DL, Thomas EA, Mayo M, Bourke PF, Sutherland CJ, Carter R, Myers G, Kemp DJ And Trenholme KR. 1999. The cytoadherence linked asexual gene family of Plasmodium falciparum: are there roles other than cytoadherence? Int J Parasitol 29: 939-944.

Howard RJ, Barnwell JW and Kao V. 1983. Antigenic variation of Plasmodium knowlesi malaria: identifi- cation of the variant antigen on infected erythrocytes. Proc Natl Acad Sci USA 80: 4129-4133.

IQbal J, Perlmann P And Berzins K. 1993. Plasmodium falciparum: analysis of the cytoadherence inhibition of the human monoclonal antibody 33G2 and of antibodies reactive with antigen Pf332. Exp Parasitol 77: 79-87.

JENSEN AT ET AL. 2004. Plasmodium falciparum associated with severe childhood malaria preferentially expresses PfEMP1 encoded by group A var genes. J Exp Med 199: 1179-1190.

Kaul DK, Roth-Jr EF, Nagel RL, Howard RJ AND HandunnetTi SM. 1991. Rosetting of Plasmodium falciparum-infected red blood cells with uninfected red blood cells enhances microvascular obstruction under flow conditions. Blood 78: 812-819.

Kaviratne M, Khan SM, Jarra W and Preiser PR. 2002. Small variant STEVOR antigen is uniquely located within Maurer's clefts in Plasmodium falciparum-infected red blood cells. Eukaryot Cell 1: 926-935.

Kikuchi M, Looareesuwan S, Ubalee R, Tasanor O, Suzuki F, Wattanagoon Y, Na-BangChang K, Kimura A, Aikawa M and Hirayama K. 2001. Association of adhesion molecule PECAM-1/CD31 polymorphism with susceptibility to cerebral malaria in Thais. Parasitol Int 50: 235-239.

Kirchgatter K and del Portillo HA. 2002. Association of severe noncerebral Plasmodium falciparum malaria in Brazil with expressed PfEMP1 DBL1 alpha sequences lacking cysteine residues. Mol Med 8: 16-23.

Kirchgatter K, Mosbach R and del Portillo HA. 2000. Plasmodium falciparum: DBL-1 var sequence analysis in field isolates from central Brazil. Exp Parasitol 95: 154-157.

Kun JF, Schmidt-Ott RJ, Lehman LG, Lell B, LuCKner D, Greve B, Matousek P and Kremsner PG. 1998. Merozoite surface antigen 1 and 2 genotypes and rosetting of Plasmodium falciparum in severe and mild malaria in Lambarene, Gabon. Trans R Soc Trop Med Hyg 92: 110-114.

Kyes S, Taylor H, Craig A, Marsh K and Newbold C. 1997. Genomic representation of var gene sequences in Plasmodium falciparum field isolates from different geographic regions. Mol Biochem Parasitol 87: 235-238. 
Kyes SA, Rowe JA, Kriek N And Newbold CI. 1999. Rifins: a second family of clonally variant proteins expressed on the surface of red cells infected with Plasmodium falciparum. Proc Natl Acad Sci USA 96: 9333-9338.

LALloo DG ET AL. 1996. Severe and complicated falciparum malaria in Melanesian adults in Papua New Guinea. Am J Trop Med Hyg 55: 119-124.

LANGReth SG AND ReEse RT. 1979. Antigenicity of the infected-erythrocyte and merozoite surfaces in falciparum malaria. J Exp Med 150: 1241-1254.

Leech JH, Barnwell JW, Miller LH AND Howard RJ. 1984. Identification of a strain-specific malarial antigen exposed on the surface of Plasmodium falciparum-infected erythrocytes. J Exp Med 159: 1567-1575.

Lekana-Douki JB, Traore B, Costa FT, Fusai T, Pouvelle B, Sterkers Y, Scherf A and Gysin J. 2002. Sequestration of Plasmodium falciparuminfected erythrocytes to chondroitin sulfate $\mathrm{A}$, a receptor for maternal malaria: monoclonal antibodies against the native parasite ligand reveal panreactive epitopes in placental isolates. Blood 100: 1478-1483.

Limpaiboon T, Taylor DW, Jones G, Geysen HM AND SAUl A. 1990. Characterization of a Plasmodium falciparum epitope recognized by a monoclonal antibody with broad isolate and species specificity. Southeast Asian J Trop Med Public Health 21: 388-396.

Lowe BS, Mosobo M and Bull PC. 1998. All four species of human malaria parasites form rosettes. Trans R Soc Trop Med Hyg 92: 526.

Luse SA AND Miller LH. 1971. Plasmodium falciparum malaria. Ultrastructure of parasitized erythrocytes in cardiac vessels. Am J Trop Med Hyg 20: 655-660.

Luxemburger C, Thwai KL, White NJ, Webster HK, Kyle DE, Maelankirri L, Chongsuphajaisiddhi T AND Nosten F. 1996. The epidemiology of malaria in a Karen population on the western border of Thailand. Trans R Soc Trop Med Hyg 90: 105-111.

MacPherson GG, Warrell MJ, White NJ, LooAREESUWAN S AND WARRELL DA. 1985. Human cerebral malaria. A quantitative ultrastructural analysis of parasitized erythrocyte sequestration. Am J Pathol 119: 385-401.
MARSH K AND Howard RJ. 1986. Antigens induced on erythrocytes by $P$. falciparum: expression of diverse and conserved determinants. Science 231: 150-153.

Marsh K, Marsh VM, Brown J, Whittle HC and GreENwoOd BM. 1988. Plasmodium falciparum: the behavior of clinical isolates in an in vitro model of infected red blood cell sequestration. Exp Parasitol 65: 202-208.

Mattei D And Scherf A. 1992. The Pf332 gene of Plasmodium falciparum codes for a giant protein that is translocated from the parasite to the membrane of infected erythrocytes. Gene 110: 71-79.

McCormick CJ, Craig A, Roberts D, Newbold CI AND BERENDT AR. 1997. Intercellular adhesion molecule-1 and CD36 synergize to mediate adherence of Plasmodium falciparum-infected erythrocytes to cultured human microvascular endothelial cells. J Clin Invest 100: 2521-2529.

McLean SA, Pearson CD and Phillips RS. 1982. Plasmodium chabaudi: antigenic variation during recrudescent parasitaemias in mice. Exp Parasitol 54: 296-302.

Mendis KN, Ihalamulla RI and David PH. 1988. Diversity of Plasmodium vivax-induced antigens on the surface of infected human erythrocytes. Am J Trop Med Hyg 38: 42-46.

Metzger WG, Mordmuller BG and Kremsner PG. 1995. Malaria pigment in leucocytes. Trans R Soc Trop Med Hyg 89: 637-638.

Miller LH. 1969. Distribution of mature trophozoites and schizonts of Plasmodium falciparum in the organs of Aotus trivirgatus, the night monkey. Am J Trop Med Hyg 18: 860-865.

Miller LH, Good MF ANd Milon G. 1994. Malaria pathogenesis. Science 264: 1878-1883.

Miller LH, Baruch DI, Marsh K and Doumbo OK. 2002. The pathogenic basis of malaria. Nature 415: 673-679.

Newbold C, Warn P, Black G, Berendt A, Craig A, Snow B, Msobo M, Peshu N and Marsh K. 1997b. Receptor-specific adhesion and clinical disease in Plasmodium falciparum. Am J Trop Med Hyg 57: 389-398.

Newbold C, Craig A, Kyes S, Rowe A, FernandezReyes D And Fagan T. 1999. Cytoadherence, pathogenesis and the infected red cell surface in Plasmodium falciparum. Int J Parasitol 29: 927-937. 
Newbold CI. 1999. Antigenic variation in Plasmodium falciparum: mechanisms and consequences. Curr Opin Microbiol 2: 420-425.

Newbold CI, Pinches R, Roberts DJ And Marsh K. 1992. Plasmodium falciparum: the human agglutinating antibody response to the infected red cell surface is predominantly variant specific. Exp Parasitol 75: 281-292.

Newbold Ci, Craig AG, Kyes S, Berendt AR, Snow RW, Peshu N and Marsh K. 1997a. PfEMP1, polymorphism and pathogenesis. Ann Trop Med Parasitol 91: 551-557.

Nguyen PH, Day N, Pram TD, Ferguson DJ and White NJ. 1995. Intraleucocytic malaria pigment and prognosis in severe malaria. Trans $\mathrm{R}$ Soc Trop Med Hyg 89: 200-204.

Nogueira PA, Wunderlich G, Tada MS, Costa JN, Menezes MJ, Scherf A and Pereira-da-Silva LH. 2002. Plasmodium falciparum: analysis of transcribed var gene sequences in natural isolates from the Brazilian Amazon region. Exp Parasitol 101: 111-120.

Noviyanti R, Brown GV, Wickham ME, Duffy MF, Cowman AF And Reeder JC. 2001. Multiple var gene transcripts are expressed in Plasmodium falciparum infected erythrocytes selected for adhesion. Mol Biochem Parasitol 114: 227-237.

Oberhoffer M, Stonans I, Russwurm S, Stonane E, VOGELSANG H, Junker U, JAger L AND REINHART K. 1999. Procalcitonin expression in human peripheral blood mononuclear cells and its modulation by lipopolysaccharides and sepsis-related cytokines in vitro. J Lab Clin Med 134: 49-55.

Ockenhouse CF, Klotz FW, TANDON NN AND JAMIESON GA. 1991. Sequestrin, a CD36 recognition protein on Plasmodium falciparum malaria-infected erythrocytes identified by anti-idiotype antibodies. Proc Natl Acad Sci USA 88: 3175-3179.

Ockenhouse CF, Tegoshi T, Maeno Y, Benjamin C, Ho M, Kan KE, Thway Y, Win K, Aikawa M and LoBB RR. 1992. Human vascular endothelial cell adhesion receptors for Plasmodium falciparuminfected erythrocytes: roles for endothelial leukocyte adhesion molecule 1 and vascular cell adhesion molecule 1. J Exp Med 176: 1183-1189.

Oh SS, Voigt S, Fisher D, Yi SJ, LeRoy PJ, DerICK LH, LiU S AND Chishti AH. 2000. Plasmo- dium falciparum erythrocyte membrane protein 1 is anchored to the actin-spectrin junction and knobassociated histidine-rich protein in the erythrocyte skeleton. Mol Biochem Parasitol 108: 237-247.

Oquendo P, Hundt E, Lawler J and Seed B. 1989. CD36 directly mediates cytoadherence of Plasmodium falciparum parasitized erythrocytes. Cell 58: 95-101.

Paget-McNicol S, Gatton M, Hastings I and Saul A. 2002. The Plasmodium falciparum var gene switching rate, switching mechanism and patterns of parasite recrudescence described by mathematical modelling. Parasitology 124: 225-235.

Pongponratn E, Riganti M, Punpoowong B and AIKAWA M. 1991. Microvascular sequestration of parasitized erythrocytes in human falciparum malaria: a pathological study. Am J Trop Med Hyg 44: $168-175$

ReEder JC AND Brown GV. 1996. Antigenic variation and immune evasion in Plasmodium falciparum malaria. Immunol Cell Biol 74: 546-554.

Reeder JC, Rogerson SJ, AL-Yaman F, Anders RF, Coppel RL, Novakovic S, Alpers MP and Brown GV. 1994. Diversity of agglutinating phenotype, cytoadherence, and rosette-forming characteristics of Plasmodium falciparum isolates from Papua New Guinean children. Am J Trop Med Hyg 51: 45-55.

Reeder JC, Cowman AF, Davern KM, Beeson JG, Thompson JK, Rogerson SJ and Brown GV. 1999. The adhesion of Plasmodium falciparum-infected erythrocytes to chondroitin sulfate $\mathrm{A}$ is mediated by P. falciparum erythrocyte membrane protein 1 . Proc Natl Acad Sci USA 96: 5198-5202.

Ringwald P, PEYRon F, LEPERS JP, RABARISON P, RAKoTOMALALA C, RAZANAMPARANY M, RABODONIRINA M, Roux J ANd Le Bras J. 1993. Parasite virulence factors during falciparum malaria: rosetting, cytoadherence, and modulation of cytoadherence by cytokines. Infect Immun 61: 5198-5204.

Roberts DD, Sherwood JA, Spitalnik SL, Panton LJ, Howard RJ, Dixit VM, Frazier WA, Miller LH AND GinsBurg V. 1985. Thrombospondin binds falciparum malaria parasitized erythrocytes and may mediate cytoadherence. Nature 318: 64-66.

Roberts DJ, Craig AG, Berendt AR, Pinches R, Nash G, Marsh K and Newbold CI. 1992. Rapid switch- 
ing to multiple antigenic and adhesive phenotypes in malaria. Nature 357: 689-692.

Robinson BA, Welch TL AND Smith JD. 2003. Widespread functional specialization of Plasmodium falciparum erythrocyte membrane protein 1 family members to bind CD36 analysed across a parasite genome. Mol Microbiol 47: 1265-1278.

Rogerson SJ, Chaiyarou SC, Ng K, Reeder JC and Brown GV. 1995. Chondroitin sulfate $A$ is a cell surface receptor for Plasmodium falciparum-infected erythrocytes. J Exp Med 182: 15-20.

Rowe A, Obeiro J, Newbold CI AND Marsh K. 1995. Plasmodium falciparum rosetting is associated with malaria severity in Kenya. Infect Immun 63: 2323-2326.

Rowe JA, Moulds JM, Newbold CI and Miller LH. 1997. P. falciparum rosetting mediated by a parasite-variant erythrocyte membrane protein and complement-receptor 1 . Nature 388: 292-295.

Rowe JA, Rogerson SJ, Raza A, Moulds JM, KaZatchkine MD, Marsh K, Newbold CI, AtKinSON JP AND Miller LH. 2000. Mapping of the region of complement receptor (CR) 1 required for Plasmodium falciparum rosetting and demonstration of the importance of CR1 in rosetting in field isolates. J Immunol 165: 6341-6346.

Rubio JP, Thompson JK And Cowman AF. 1996. The var genes of Plasmodium falciparum are located in the subtelomeric region of most chromosomes. Embo J 15: 4069-4077.

Scherf A, Hernandez-Rivas R, Buffet P, Bottius E, Benatar C, Pouvelle B, Gysin J and Lanzer M. 1998. Antigenic variation in malaria: in situ switching, relaxed and mutually exclusive transcription of var genes during intra-erythrocytic development in Plasmodium falciparum. Embo J 17: 5418-5426.

Scholander C, Treutiger CJ, Hultenby K and WAHLGREN M. 1996. Novel fibrillar structure confers adhesive property to malaria-infected erythrocytes. Nat Med 2: 204-208.

Siano JP, Grady KK, Millet P and Wick TM. 1998. Short report: Plasmodium falciparum: cytoadherence to alpha (v) beta3 on human microvascular endothelial cells. Am J Trop Med Hyg 59: 77-79.

Sim BK, Chitnis CE, Wasniowska K, Hadley TJ and MiLleR LH. 1994. Receptor and ligand domains for invasion of erythrocytes by Plasmodium falciparum. Science 264: 1941-1944.

Smith JD, Chitnis CE, Craig AG, Roberts DJ, Hudson-Taylor DE, Peterson DS, Pinches R, NewBOLD CI AND Miller LH. 1995. Switches in expression of Plasmodium falciparum var genes correlate with changes in antigenic and cytoadherent phenotypes of infected erythrocytes. Cell 82: 101-110.

Smith JD, Craig AG, Kriek N, Hudson-Taylor D, Kyes S, Fagen T, Pinches R, Baruch DI, Newbold CI AND Miller LH. 2000a. Identification of a Plasmodium falciparum intercellular adhesion molecule1 binding domain: a parasite adhesion trait implicated in cerebral malaria. Proc Natl Acad Sci USA 97: 1766-1771.

Smith JD, Subramanian G, Gamain B, Baruch DI AND Miller LH. 2000b. Classification of adhesive domains in the Plasmodium falciparum erythrocyte membrane protein 1 family. Mol Biochem Parasitol 110: 293-310.

Smith JD, Gamain B, Baruch DI and Kyes S. 2001. Decoding the language of var genes and Plasmodium falciparum sequestration. Trends Parasitol 17: 538-545.

SNOW RW ET AL. 1997. Relation between severe malaria morbidity in children and level of Plasmodium falciparum transmission in Africa. Lancet 349: 16501654.

Snow RW, Guerra CA, NoOr AM, Myint HY AND HaY SI. 2005. The global distribution of clinical episodes of Plasmodium falciparum malaria. Nature 434: 214-217.

Su XZ, Heatwole VM, Wertheimer SP, Guinet F, Herrfeldt JA, Peterson DS, Ravetch JA and Wellems TE. 1995. The large diverse gene family var encodes proteins involved in cytoadherence and antigenic variation of Plasmodium falciparuminfected erythrocytes. Cell 82: 89-100.

Taylor HM, Kyes SA, Harris D, Kriek N and NewBOLD CI. 2000. A study of var gene transcription in vitro using universal var gene primers. Mol Biochem Parasitol 105: 13-23.

Thompson JK, Rubio JP, Caruana S, Brockman A, Wickham ME and Cowman AF. 1997. The chromosomal organization of the Plasmodium falciparum var gene family is conserved. Mol Biochem Parasitol 87: 49-60. 
Tran TH ET AL. 1996. A controlled trial of artemether or quinine in Vietnamese adults with severe falciparum malaria. N Engl J Med 335: 76-83.

Traore B, Muanza K, Looareesuman S, Supavej S, Khusmith S, Danis M, Viriyavejakul P and Gay F. 2000. Cytoadherence characteristics of Plasmodium falciparum isolates in Thailand using an in vitro human lung endothelial cells model. Am J Trop Med Hyg 62: 38-44.

Trenholme KR, Gardiner DL, Holt DC, Thomas EA, Cowman AF AND Kemp DJ. 2000. clag9: A cytoadherence gene in Plasmodium falciparum essential for binding of parasitized erythrocytes to CD36. Proc Natl Acad Sci USA 97: 4029-4033.

Treutiger CJ, Hedlund I, Helmby H, Carlson J, JePson A, Twumasi P, Kwiatkowski D, Greenwood BM AND WAHLGREN M. 1992. Rosette formation in Plasmodium falciparum isolates and anti-rosette activity of sera from Gambians with cerebral or uncomplicated malaria. Am J Trop Med Hyg 46: 503-510.

Treutiger CJ, Heddini A, Fernandez V, Muller WA AND WAHLGREN M. 1997. PECAM-1/CD31, an endothelial receptor for binding Plasmodium falciparum-infected erythrocytes. Nat Med 3: 14051408.

Treutiger CJ, Scholander C, Carlson J, McAdam KP, Raynes JG, FALKSVEden L and WahlgRen M. 1999. Rouleaux-forming serum proteins are involved in the rosetting of Plasmodium falciparum-infected erythrocytes. Exp Parasitol 93: 215-224.

Udomsangpetch R, Wahlin B, Carlson J, Berzins K, Toril M, Aikawa M, Perlmann P And Wahlgren M. 1989. Plasmodium falciparum-infected erythrocytes form spontaneous erythrocyte rosettes. J Exp Med 169: 1835-1840.

Udomsangpetch R, Brown AE, Smith CD And WebSTER HK. 1991. Rosette formation by Plasmodium coatneyi-infected red blood cells. Am J Trop Med Hyg 44: 399-401.

Udomsangpetch R, Thanikkul K, Pukrittayakamee S AND White NJ. 1995. Rosette formation by Plasmodium vivax. Trans R Soc Trop Med Hyg 89: 635-637.

UdomsangPetch R, TAYlor BJ, LOOAREESUWAN S, White NJ, Elliott JF AND Ho M. 1996. Receptor specificity of clinical Plasmodium falciparum isolates: nonadherence to cell-bound E-selectin and vascular cell adhesion molecule-1. Blood 88: 2754-2760.

Vogt AM, Barragan A, Chen Q, Kironde F, SpillMANN D AND WAHLGREN M. 2003. Heparan sulfate on endothelial cells mediates the binding of Plasmodium falciparum-infected erythrocytes via the DBL1alpha domain of PfEMP1. Blood 101: 24052411.

Wahlgren M, Carlson J, RuangJirachuporn W, Conway D, Helmby H, Martinez A, Patarroyo ME AND RILEY E. 1990. Geographical distribution of Plasmodium falciparum erythrocyte rosetting and frequency of rosetting antibodies in human sera. Am J Trop Med Hyg 43: 333-338.

Wahlgren M, Carlson J, Helmby H, Hedlund I AND Treutiger CJ. 1992. Molecular mechanisms and biological importance of Plasmodium falciparum erythrocyte rosetting. Mem Inst Oswaldo Cruz 87: 323-329.

Wahlgren M, Fernandez V, Scholander C And Carlson J. 1994. Rosetting. Parasitol Today 10: 73-79.

Ward CP, Clottey GT, Dorris M, Ji DD and Arnot DE. 1999. Analysis of Plasmodium falciparum PfEMP-1/var genes suggests that recombination rearranges constrained sequences. Mol Biochem Parasitol 102: 167-177.

WeBER JL. 1988. Interspersed repetitive DNA from Plasmodium falciparum. Mol Biochem Parasitol 29: 117-124.

Whang KT, Vath SD, Becker KL, SNider RH, Nylen ES, Muller B, Li Q, Tamarkin L and White JC. 1999. Procalcitonin and proinflammatory cytokine in interactions in sepsis. Shock 12: 268-273.

WHO. 1990. Severe and complicated malaria. World Health Organization, Division of Control of Tropical Diseases. Trans R Soc Trop Med Hyg 84: 1-65.

WHO. 1996. World malaria situation in 1993. Wkly Epidemiol Rec 71: 17-22.

WHO. 2000. Severe falciparum malaria. Trans R Soc Trop Med Hyg 94: S1/1-S1/90. 